\title{
PENGGUNAAN PERMAINAN DADU LITERASI UNTUK PERKEMBANGAN SOSIAL EMOSIONAL DI TK AL-AQSHO KONAWE SELATAN
}

\author{
La Hewi \\ Institut Agama Islam Negeri Kendari \\ Email: lahewih15@gmail.com
}

Article received: 02 Desember 2019, Review process: 17 Januari 2020

Article published: 30 Maret 2020

\begin{abstract}
Play as the main activity and is very desirable to be done by children to be the best means for stimulating early childhood development activities so teachers need to design creative games that are appropriate and effective for stimulating child development. PAUD unit educators do not take advantage of creative games in the learning activities carried out. The use of a literacy dice game is used as a medium for stimulating the emotional social development of early childhood in group A TK Al-Aqsho, Konawe Selatan District. The research method used is action research. The model chosen for action is the Kemmis and Taggart cycle which has four stages of planning, action, observation and reflection. Data on children's social emotional development obtained from observation and documentation are then analyzed using a percentage. The study was conducted in two cycles, each cycle having three meetings. The results showed that the use of literacy dice games was effective for stimulating emotional social development of early childhood.
\end{abstract}

Keywords: Literacy Dice Game, Social Emotional Children

\begin{abstract}
Abstrak
Bermain sebagai aktivitas utama dan sangat diminati untuk dilakukan oleh anak menjadi sarana yang paling baik untuk kegiatan stimulasi perkembangan anak usia dini sehingga guru perlu merancang permainan kreatif yang tepat dan efektif untuk stimulasi perkembangan anak. Pendidik satuan PAUD kurang memanfaatkan permainan kreatif dalam kegiatan pembelajaran yang dilakukan. Penggunaan permainan dadu literasi sebagai media stimulasi perkembangan sosial emosional anak usia dini kelompok A TK Al-Aqsho Kabupaten Konawe Selatan. Metode penelitian yang digunakan adalah penelitian tindakan. Model yang dipilih untuk melakukan tindakan yaitu siklus model Kemmis dan Taggart yang memiliki empat tahapan perencanaan, tindakan, observasi dan refleksi. Data perkembangan sosial emosional anak yang diperoleh dari observasi dan dokumentasi selanjutnya dianalisis dengan menggunakan presentase. Penelitian dilakukan dua siklus, setiap siklus dilakukan tiga kali
\end{abstract}


pertemuan. Hasil penelitian menunjukkan bahwa penggunakan permainan dadu literasi efektif untuk stimulasi perkembangan sosial emosional anak usia dini.

Kata Kunci: Permainan Dadu Literasi, Sosial Emosional Anak

\section{PENDAHULUAN}

Bermain merupakan aktivitas utama anak usia dini dalam memahami sesuatu dan mengeksplor pengalaman yang dimiliki untuk mendapatkan pengetahuan yang baru akan menjadi sesuatu yang sangat efektif untuk stimulasi perkembangan anak usia dini. Suatu permainan yang di desain dengan perencanaan yang baik untuk tujuan pembelajaran dan memfokuskan kegiatan bermain pada salah satu aspek perkembangan anak akan sangat efektif untuk stimulasi perkembangan anak. Bermain bagi anak selain mendatangkan kegembiraan dan interaksi dengan teman-teman sebayanya, juga merupakan proses belajar yang menyebabkan terjadinya perubahan yang lebih baik pada aspek-aspek perkembangan anak usia dini. Sebagaimana yang dikemukakan oleh Jawati melalui hasil penelitiannya menemukan bahwa permainan ludo geometri dapat meningkatkan perkembangan kognitif anak usia 5-6 tahun dalam aspek mengenal bentuk geometri, mengenal bilangan dan mengelompokkan warna (Jawati, 2013, p. 250). Begitu pula dengan hasil penelitian yang dilakukan oleh Putri yang dalam penelitiannya tentang permainan tradisional efektif dalam meningkatkan penyesuaian sosial anak usia 4-5 tahun (Putri, 2013, p. 1). Satriana juga mengemukakan bahwa permainan tradisional berbasis budaya sunda dapat menjadi sarana stimulasi perkembangan anak usia dini (Satriana, 2013, p. 83). Beberapa hal di atas membawa konsekuensi pemikiran bahwa bermain haruslah dilakukan dengan perencanaan dan menggunakan media yang sesuai perkembangan anak usia dini dan tidak sekedar untuk kegiatan selingan mengisi waktu. Sehingga dengan bermain anak memiliki pengetahuan yang sesuai dengan realita atau dengan kata lain anak tidak salah konsep pada pembelajaran yang dilakukan oleh guru. Sebagai aktivitas yang utama dalam pembelajaran, bermain hendaknya dikelola dengan perencanaan yang baik dan sistematis. Desmita mengemukakan bahwa permainan merupakan salah satu bentuk aktivitas sosial yang dominan pada awal masa kanakkanak (Desmita, 2013, p. 141) sehingga guru PAUD sebagai pengelola proses pembelajaran 
semestinya mampu memilih media yang sesuai dengan aspek perkembangan yang ingin dikembangkan pada anak.

Permainan dadu literasi merupakan media pembelajaran yang dirancang dan dibuat sendiri oleh peneliti sebagai sarana pembelajaran sambil bermain yang terbuat dari kardus dengan dilapisi kain flanel berbentuk kubus dan memiliki enam sisi, pada setiap sisi terdapat angka satu sampai angka enam. Cara memainkan permainan dadu literasi sama seperti memainkan permainan ular tangga yaitu dimainkan secara kelompok, masing-masing kelompok berjumlah dua anak, anak yang pertama berperan sebagai pelempar dadu sementara anak yang kedua berperan sebagai pion yang akan melangkahi beberapa kotak yang berisi huruf abjad secara keseluruhan mulai dari huruf A sampai huruf Z, kelompok yang menang adalah kelompok yang memiliki pion lebih dahulu sampai di huruf terakhir dari abjad.

Perkembangan sosial emosional merupakan salah satu dari beberapa aspek perkembangan yang harus dikembangkan pada peserta didik yang ada di lembaga-lembaga pendidikan anak usia dini. Hurlock menyatakan bahwa perkembangan sosial adalah perolehan kemampuan berperilaku yang sesuai dengan tuntutan sosial (Hurlock, 2013, p. 250). Perkembangan sosial emosional memiliki keterkaitan yang saling mempengaruhi yang oleh Hurlock dinyatakan bahwa emosi mempengaruhi penyesuaian pribadi dan sosial anak (Hurlock, 2013, p. 211). Nurmalitasari menyatakan bahwa mengembangkan sosial emosional anak harus dilakukan sejak di taman kanak-kanak karena masa pertama anak mengembangkan pergaulan dengan teman sebaya yang berada di lingkungan rumah dan di luar lingkungan rumah adalah di lembaga pendidikan anak usia dini (Nurmalitasari, 2015, p. 111). Peraturan menteri pendidikan dan kebudayaan nomor 137 tentang standar nasional pendidikan anak usia dini menyatakan bahwa salah satu aspek perkembangan yang harus dikembangkan di lembaga pendidikan anak usia dini adalah sosial emosional. Adapun indikator capaian perkembangan untuk anak usia 4-5 tahun yaitu: 
Tabel 1. Indikator dan Capaian Perkembangan Sosial Emosional Anak Usia 4-5 tahun

\begin{tabular}{ll}
\hline \multicolumn{1}{c}{$\begin{array}{l}\text { Indikator perkembangan Sosial } \\
\text { Emosional }\end{array}$} & Capaian perkembangan anak usia 4-5 tahun \\
\hline Kesadaran diri & - Menunjukkan sikap mandiri dalam memilih kegiatan \\
& - Mengendalikan perasaan \\
& - Memahukkan rasa percaya diri \\
& - Memiliki sikap gigih (tidak mudah menyerah) \\
Rasa tanggung jawab untuk diri & - Menjaga diri sendiri dari lingkungannya \\
sendiri dan orang lain & - Menghargai keunggulan orang lain \\
& - Mau berbagi, menolong, dan membantu teman \\
Perilaku prososial & Menunjukan antusiasme dalam melakukan permainan \\
& kompetitif secara positif \\
\hline
\end{tabular}

Berdasarkan indikator dan capaian perkembangan sosial emosional menurut Peraturan menteri pendidikan dan kebudayaan nomor 137 tentang standar nasional pendidikan anak usia dini menunjukkan bahwa indikator perkembangan sosial emosional anak meliputi kesadaran diri, rasa tanggung jawab untuk diri sendiri dan orang lain serta perilaku prososial. Hurlock mengemukakan bahwa masa kanak-kanak dini yaitu usia 2-6 tahun memiliki periode perkembangan anak berusaha untuk mengendalikan lingkungan dan mulai belajar menyesuaikan diri secara sosial (Hurlock, 2013, p. 38). Lebih lanjut Santrock mengemukakan bahwa masa kanak-kanak awal sebelum sekolah dasar yaitu usia 3-5 tahun anak berada pada tahap perkembangan inisiatif versus rasa bersalah yang oleh Erikson (1968) disebut dengan Initiative versus guilt (Santrock, 2012, p. 96). Parten (1932) dalam Papalia dan Feldman menyatakan bahwa bermain memiliki dimensi sosial dengan bermain anak akan lebih koperatif dan interaktif (Papalia, 2015, p. 288).

Berdasarkan pemaparan yang telah dikemukakan di atas bahwa perkembangan sosial emosional merupakan salah satu aspek yang harus dikembangkan pada anak usia dini. Pengembangan sosial emosional yang efektif yaitu melalui kegiatan bermain. Khasanah, Prasetyo dan Rakhmawati mengemukakan bahwa permainan tradisional dapat menjadi media stimulasi aspek perkembangan anak usia dini (Khasanah, I., Prasetyo, 2011, p. 91). Begitu dengan Munawaroh yang menyatakan bahwa permainan tradisional engklek efektif sebagai 
sarana stimulasi perkembangan anak usia dini (Munawaroh, 2017, p. 86). Beberapa pemaparan di atas menunjukkan bahwa permainan efektif untuk stimulasi perkembangan anak bukan hanya satu aspek melainkan semua aspek perkembangan anak akan berkembang dengan baik jika diberikan stimulus dengan bermain. Sugiono dan Kuntjojo mengemukakan bahwa permainan efektif untuk kemampuan pra-calistung anak usia dini (Kuntjojo, 2016, p. 255). Begitu juga dengan permainan dadu dapat digunakan untuk pengembangan matematika anak usia dini (Rohmah, N., 2016, p. 44). Nurbayani melalui temuan disertainya menyatakan bahwa penerapan bermain dadu geometri berpengaruh terhadap keterampilan sosial anak usia dini (Nurbayani, 2011). Andryani, Raga dan Suartama mengemukakan bahwa Penerapan Metode Demonstrasi Berbantuan Media Dadu untuk Meningkatkan Kemampuan Mengenal Konsep Bilangan Pada Anak di TK (Andriyani, P. W. S., Raga, G., \& Suartama, 2013, p. 10). Berdasarkan pemaparan di atas tentang temuan penelitian yang telah ada tentang permainan untuk stimulasi perkembangan anak usia dini, peneliti memiliki keyakinan bahwa penggunaan permainan dadu literasi dapat mengembangkan kemampuan sosial emosional anak usia 4-5 tahun di TK Al-Aqsho Kabupaten Konawe Selatan.

\section{METODOLOGI}

Metode penelitian yang digunakan dalam penelitian ini adalah penelitian tindakan kelas (action research). Iskandar menyatakan bahwa penelitian tindakan merupakan aktivitas penelitian yang dilakukan oleh guru dan dosen dalam rangka memperbaiki dan meningkatkan kualitas dan kuantitas proses pembelajaran (Iskandar, 2009, p. 20). Penggunaan metode penelitian ini untuk melihat kegiatan belajar di satuan PAUD dengan memberikan tindakan tertentu yang sengaja dilakukan untuk melihat perkembangan dan peningkatan aspek perkembangan sosial emosional anak usia 4-5 tahun yang ada di TK Al-Aqsho Kabupaten Konawe Selatan. Penelitian akan dilakukan selama dua siklus yaitu siklus I dan siklus II, yang masing-masing siklus terdiri dari tiga kali pertemuan. Model penelitian tindakan yang dipilih adalah siklus model Kemmis dan Taggart yang memiliki empat tahapan perencanaan, tindakan, observasi dan refleksi (Arikunto, 2009, p. 17). Adapun subjek penelitian ini adalah anak kelompok A TK Al-Aqsho Kabupaten Konawe Selatan yang berjumlah 19 orang dan 
terdiri dari 7 orang siswa laki dan 12 orang siswa perempuan yang berada pada rentang usia 45 tahun.

Kehadiran peneliti sebagai kolaborator sekaligus observator dalam pelaksanaan pembelajaran di kelas. Guru yang terlibat berjumlah dua orang, keterlibatan guru mulai dari perencanaan tindakan, pelaksanaan dan refleksi serta yang terakhir revisi untuk menyusun siklus selanjutnya. Kegiatan penelitian dilakukan sesuai dengan perencanaan yang telah dibuat sebelumnya, yaitu pelaksanaan pembelajaran dilakukan dengan berpedoman pada rencana pelaksanaan pembelajaran harian dan rencana pelaksanaan pembelajaran mingguan yang telah dibuat bersama. Dengan fokus tindakan yaitu permainan dadu literasi untuk perkembangan sosial emosional anak sesuai dengan tahapan usia anak usia dini pada aspek anak dapat mengendalikan perasaan, anak dapat memahami peraturan dan disiplin, anak dapat menunjukkan antusiasme dalam melakukan suatu permainan, anak dapat menghargai keunggulan orang lain, Memiliki sikap gigih/tidak mudah menyerah dan Anak dapat berbagi dengan orang lain.

Data penelitian dikumpulkan dengan menggunakan metode pengumpulan data yaitu observasi dan catatan lapangan. Observasi digunakan untuk mendapatkan data tentang pelaksanaan pembelajaran dengan menggunakan permainan dadu literasi untuk perkembangan sosial emosional yang sesuai dengan tahapan usia anak berdasarkan langkah-langkah pembelajaran yang ada dalam rencana pelaksanaan pembelajaran harian. Sementara untuk catatan lapangan digunakan untuk mendapatkan semua data tentang pelaksanaan pembelajaran dan tidak hanya fokus pada langkah-langkah pembelajaran yang ada dalam rencana pelaksanaan pembelajaran harian tetapi semua hal yang dilihat, didengar, dialami dan rasakan selama menjadi observator pelaksanaan pembelajaran. Data yang diperoleh dari observasi dan catatan lapangan tentang perkembangan sosial emosional anak akan analisis dengan menggunakan teknik presentase dengan rumus (Purwanto, 2009, p. 102) sebagai berikut: 


$$
\begin{array}{ll}
P=\frac{F}{N} \times 100 \% & \text { Keterangan : } \\
& \mathrm{P}=\text { Angka Presentase } \\
& \mathrm{F}=\text { Frekuensi yang Dicari Presentasenya } \\
& \mathrm{N}=\text { Jumlah Frekuensi atau Banyaknya Individu }
\end{array}
$$

Perkembangan aspek sosial emosional anak ditentukan menggunakan kriteria yang ditetapkan oleh peneliti dengan memodifikasi dan berpedoman pada kriteria ketuntasan belajar dari Arikunto (Arikunto, 2013) yaitu :

$$
\begin{array}{ll}
81 \%-100 \% & \text { : sangat tinggi perkembangan sosem anak } \\
61 \%-80 \% & \text { : tinggi perkembangan sosem anak } \\
41 \%-60 \% & \text { : sedang perkembangan sosem anak } \\
21 \%-40 \% & \text { : rendah perkembangan sosem anak }
\end{array}
$$

\section{HASIL DAN PEMBAHASAN}

Penelitian ini telah dilaksanakan di TK Al-Aqsho Kabupaten Konawe Selatan, dengan subjek penelitian anak kelompok A pada rentang usia 4-5 tahun yang diberikan perlakuan atau tindakan berupa penggunaan permainan dadu literasi untuk perkembangan anak pada aspek sosial emosional. Hasil penelitian berupa data pra tindakan atau sebelum diberikan permainan dadu literasi literasi untuk dilihat aspek sosial emosionalnya dan data setelah diberikan tindakan yaitu pembelajaran dengan menggunakan permainan dadu literasi.

Berdasarkan hasil observasi dan catatan lapangan tentang capaian perkembangan untuk aspek sosial emosional pra tindakan yaitu sebagai berikut:

Tabel 2. Kemampuan Sosial Emosional Anak Pra Tindakan

\begin{tabular}{|l|l|l|l|l|}
\hline \multirow{2}{*}{ Aspek Sosem yang Dinilai } & \multicolumn{3}{l|}{ Hasil Penilaian } \\
\cline { 2 - 5 } & BB & MB & BSH & BSB \\
\hline Anak dapat mengendalikan perasaan & $16 \%$ & $53 \%$ & $21 \%$ & $10 \%$ \\
\hline $\begin{array}{l}\text { Anak dapat menunjukkan antusiasme dalam melakukan suatu } \\
\text { permainan }\end{array}$ & $11 \%$ & $26 \%$ & $37 \%$ & $26 \%$ \\
\hline Anak dapat menghargai keunggulan orang lain & $16 \%$ & $32 \%$ & $47 \%$ & $5 \%$ \\
\hline Memiliki sikap gigih/tidak mudah menyerah & $26 \%$ & $37 \%$ & $21 \%$ & $16 \%$ \\
\hline Anak dapat berbagi dengan orang lain & $42 \%$ & $26 \%$ & $21 \%$ & $11 \%$ \\
\hline
\end{tabular}


Berdasarkan hasil data pra tindakan perkembangan sosial emosional anak sesuai dengan tabel 1 diperoleh informasi bahwa pada aspek anak dapat mengendalikan perasaan sebanyak $16 \%$ atau 3 orang anak berada pada rentang penilaian belum berkembang, $53 \%$ atau 10 orang anak berada pada rentang penilaian mulai berkembang, 21\% atau 4 orang anak berada pada rentang penilaian berkembang sesuai harapan dan $10 \%$ atau 2 orang anak berada pada rentang penilaian berkembang sangat baik. Selanjutnya pada aspek anak dapat menunjukkan antusiasme dalam melakukan suatu permainan sebanyak $11 \%$ atau 2 orang anak berada pada rentang penilaian belum berkembang, 26\% atau 5 orang anak berada pada rentang penilaian mulai berkembang, $37 \%$ atau 7 orang anak berada pada rentang penilaian berkembang sesuai harapan dan $26 \%$ atau 5 orang anak berada pada rentang penilaian berkembang sangat baik. Sementara pada aspek anak dapat menghargai keunggulan orang lain sebanyak $16 \%$ atau 3 orang anak berada pada rentang penilaian belum berkembang, 32\% atau 6 orang anak berada pada rentang penilaian mulai berkembang, $47 \%$ atau 9 anak berada rentang penilaian berkembang sesuai harapan dan $5 \%$ atau 1 orang anak berada pada rentang penilaian berkembang sangat baik. Untuk aspek anak memiliki sikap gigih/tidak mudah menyerah sebanyak $26 \%$ atau 5 orang anak berada pada rentang penilaian belum berkembang, $37 \%$ atau 7 orang anak berada pada rentang penilaian mulai berkembang, $21 \%$ atau 4 anak berada rentang penilaian berkembang sesuai harapan dan 16\% atau 3 orang anak berada pada rentang penilaian berkembang sangat baik. Dan pada aspek anak dapat berbagi dengan orang sebanyak $42 \%$ atau 8 orang anak berada pada rentang penilaian belum berkembang, $26 \%$ atau 5 orang anak berada pada rentang penilaian mulai berkembang, 21\% atau 4 anak berada rentang penilaian berkembang sesuai harapan dan $11 \%$ atau 2 orang anak berada pada rentang penilaian berkembang sangat baik.

Setelah mendapatkan data perkembangan sosial emosional anak sebelum di berikan perlakuan atau pra tindakan, selanjutnya ditindaklanjuti oleh peneliti dengan menyusun perencanaan untuk melaksanakan tindakan penggunaan permainan dadu literasi untuk perkembangan sosial emosional anak. Pelaksanaan tindakan siklus satu dilaksanakan selama 3 kali pertemuan yaitu pada tanggal 9-11 september 2019. Adapun data yang diperoleh dari 
AWLADY: Jurnal Pendidikan Anak

Vol. 6, No. 1, Maret 2020

Homepage: www.syekhnurjati.ac.id/jurnal/index.php/awlady

Email : pgrasyekhnurjati@gmail.com

P-ISSN: 2541-4658

E-ISSN: 2528-7427

pelaksanaan siklus satu sebanyak tiga kali pertemuan atau pembelajaran dapat dilihat pada tabel di bawah ini:

Tabel 3. Kemampuan Sosial Emosional Anak Siklus Satu

\begin{tabular}{|c|c|c|c|c|c|c|c|c|c|c|c|c|}
\hline \multirow[b]{2}{*}{$\begin{array}{l}\text { Aspek } \\
\text { Dinilai }\end{array}$} & \multicolumn{4}{|c|}{ Pertemuan 1} & \multicolumn{4}{|c|}{ Pertemuan 2} & \multicolumn{4}{|c|}{ Pertemuan 3} \\
\hline & BB & MB & $\mathrm{BSH}$ & BSB & BB & $\begin{array}{l}\mathrm{M} \\
\mathrm{B}\end{array}$ & $\begin{array}{l}\mathrm{BS} \\
\mathrm{H}\end{array}$ & $\begin{array}{l}\text { BS } \\
\text { B }\end{array}$ & $\begin{array}{l}\mathrm{B} \\
\mathrm{B}\end{array}$ & $\begin{array}{l}\mathrm{M} \\
\mathrm{B}\end{array}$ & $\begin{array}{l}\mathrm{BS} \\
\mathrm{H}\end{array}$ & $\begin{array}{l}\text { BS } \\
\text { B }\end{array}$ \\
\hline $\begin{array}{l}\text { Anak dapat } \\
\text { mengendalikan perasaan }\end{array}$ & $\begin{array}{l}11 \\
\%\end{array}$ & $42 \%$ & $26 \%$ & $21 \%$ & $5 \%$ & $\begin{array}{l}26 \\
\%\end{array}$ & $\begin{array}{l}37 \\
\%\end{array}$ & $\begin{array}{l}32 \\
\%\end{array}$ & - & $\begin{array}{l}11 \\
\%\end{array}$ & $\begin{array}{l}42 \\
\%\end{array}$ & $\begin{array}{l}47 \\
\%\end{array}$ \\
\hline $\begin{array}{lr}\text { Anak dapat } & \text { menunjukkan } \\
\text { antusiasme } & \text { dalam } \\
\text { melakukan } & \text { suatu } \\
\text { permainan } & \end{array}$ & - & $16 \%$ & $47 \%$ & $37 \%$ & - & $\begin{array}{l}5 \\
\%\end{array}$ & $\begin{array}{l}42 \\
\%\end{array}$ & $\begin{array}{l}53 \\
\%\end{array}$ & - & - & $\begin{array}{l}32 \\
\%\end{array}$ & $\begin{array}{l}68 \\
\%\end{array}$ \\
\hline $\begin{array}{l}\text { Anak dapat menghargai } \\
\text { keunggulan orang lain }\end{array}$ & - & $32 \%$ & $52 \%$ & $16 \%$ & - & $\begin{array}{l}21 \\
\%\end{array}$ & $\begin{array}{l}47 \\
\%\end{array}$ & $\begin{array}{l}32 \\
\%\end{array}$ & - & $\begin{array}{l}5 \\
\%\end{array}$ & $\begin{array}{l}42 \\
\%\end{array}$ & $\begin{array}{l}53 \\
\%\end{array}$ \\
\hline $\begin{array}{lr}\text { Memiliki } & \text { sikap } \\
\text { gigih/tidak } & \text { mudah } \\
\text { menyerah } & \end{array}$ & $\begin{array}{l}16 \\
\%\end{array}$ & $26 \%$ & $37 \%$ & $21 \%$ & $5 \%$ & $\begin{array}{l}21 \\
\%\end{array}$ & $\begin{array}{l}42 \\
\%\end{array}$ & $\begin{array}{l}32 \\
\%\end{array}$ & - & $\begin{array}{l}16 \\
\%\end{array}$ & $\begin{array}{l}37 \\
\%\end{array}$ & $\begin{array}{l}47 \\
\%\end{array}$ \\
\hline $\begin{array}{l}\text { Anak dapat berbagi } \\
\text { dengan orang lain }\end{array}$ & $\begin{array}{l}21 \\
\%\end{array}$ & $16 \%$ & $32 \%$ & $31 \%$ & $5 \%$ & $\begin{array}{l}11 \\
\%\end{array}$ & $\begin{array}{l}26 \\
\%\end{array}$ & $\begin{array}{l}58 \\
\%\end{array}$ & - & $\begin{array}{l}5 \\
\%\end{array}$ & $\begin{array}{l}32 \\
\%\end{array}$ & $\begin{array}{l}63 \\
\%\end{array}$ \\
\hline
\end{tabular}

Berdasarkan data hasil tindakan siklus satu pertemuan pertama diperoleh perkembangan sosial emosional anak sesuai dengan tabel 2 yaitu pada aspek anak dapat mengendalikan perasaan sebanyak $11 \%$ atau 2 orang anak berada pada rentang penilaian belum berkembang, $42 \%$ atau 8 orang anak berada pada rentang penilaian mulai berkembang, $26 \%$ atau 5 orang anak berada pada rentang penilaian berkembang sesuai harapan dan $21 \%$ atau 4 orang anak berada pada rentang penilaian berkembang sangat baik. Selanjutnya pada aspek anak dapat menunjukkan antusiasme dalam melakukan suatu permainan tidak ada lagi anak yang berada pada rentang penilaian belum berkembang, $16 \%$ atau 3 orang anak berada pada rentang penilaian mulai berkembang, $47 \%$ atau 9 orang anak berada pada rentang penilaian berkembang sesuai harapan dan $37 \%$ atau 7 orang anak berada pada rentang penilaian berkembang sangat baik. Sementara pada aspek anak dapat menghargai keunggulan orang lain tidak ditemukan lagi anak yang berada pada rentang penilaian belum berkembang, $32 \%$ atau 6 orang anak berada pada rentang penilaian mulai berkembang, 52\% atau 10 anak berada rentang penilaian berkembang sesuai harapan dan 16\% atau 3 orang anak berada pada rentang penilaian berkembang sangat baik. Untuk aspek anak memiliki sikap gigih/tidak 
mudah menyerah sebanyak $16 \%$ atau 3 orang anak berada pada rentang penilaian belum berkembang, 26\% atau 5 orang anak berada pada rentang penilaian mulai berkembang, 37\% atau 7 anak berada rentang penilaian berkembang sesuai harapan dan $21 \%$ atau 4 orang anak berada pada rentang penilaian berkembang sangat baik. Dan pada aspek anak dapat berbagi dengan orang sebanyak $21 \%$ atau 4 orang anak berada pada rentang penilaian belum berkembang, $16 \%$ atau 3 orang anak berada pada rentang penilaian mulai berkembang, $32 \%$ atau 6 anak berada rentang penilaian berkembang sesuai harapan dan 31\% atau 6 orang anak berada pada rentang penilaian berkembang sangat baik.

Selanjutnya pertemuan kedua pada pelaksanaan tindakan siklus satu diperoleh perkembangan sosial emosional anak sesuai dengan tabel 2 yaitu pada aspek anak dapat mengendalikan perasaan sebanyak $5 \%$ atau 1 orang anak berada pada rentang penilaian belum berkembang, $26 \%$ atau 5 orang anak berada pada rentang penilaian mulai berkembang, 37\% atau 7 orang anak berada pada rentang penilaian berkembang sesuai harapan dan $32 \%$ atau 6 orang anak berada pada rentang penilaian berkembang sangat baik. Selanjutnya pada aspek anak dapat menunjukkan antusiasme dalam melakukan suatu permainan tidak ada lagi anak yang berada pada rentang penilaian belum berkembang, 5\% atau 1 orang anak berada pada rentang penilaian mulai berkembang, $42 \%$ atau 8 orang anak berada pada rentang penilaian berkembang sesuai harapan dan $53 \%$ atau 10 orang anak berada pada rentang penilaian berkembang sangat baik. Sementara pada aspek anak dapat menghargai keunggulan orang lain tidak ditemukan lagi anak yang berada pada rentang penilaian belum berkembang, $21 \%$ atau 4 orang anak berada pada rentang penilaian mulai berkembang, 47\% atau 9 anak berada rentang penilaian berkembang sesuai harapan dan $32 \%$ atau 6 orang anak berada pada rentang penilaian berkembang sangat baik. Untuk aspek anak memiliki sikap gigih/tidak mudah menyerah sebanyak 5\% atau 1 orang anak berada pada rentang penilaian belum berkembang, $21 \%$ atau 4 orang anak berada pada rentang penilaian mulai berkembang, $42 \%$ atau 8 anak berada rentang penilaian berkembang sesuai harapan dan $32 \%$ atau 6 orang anak berada pada rentang penilaian berkembang sangat baik. Dan pada aspek anak dapat berbagi dengan orang sebanyak $5 \%$ atau 1 orang anak berada pada rentang penilaian belum berkembang, $11 \%$ atau 2 orang anak berada pada rentang penilaian mulai berkembang, $26 \%$ atau 5 anak berada rentang 
penilaian berkembang sesuai harapan dan 58\% atau 11 orang anak berada pada rentang penilaian berkembang sangat baik.

Pada pertemuan ketiga dari pelaksanaan tindakan siklus satu diperoleh perkembangan sosial emosional anak sesuai dengan tabel 2 yaitu pada aspek anak dapat mengendalikan perasaan tidak ada lagi anak yang berada pada rentang penilaian belum berkembang, $11 \%$ atau 2 orang anak berada pada rentang penilaian mulai berkembang, $42 \%$ atau 8 orang anak berada pada rentang penilaian berkembang sesuai harapan dan $47 \%$ atau 9 orang anak berada pada rentang penilaian berkembang sangat baik. Selanjutnya pada aspek anak dapat menunjukkan antusiasme dalam melakukan suatu permainan tidak ada lagi anak yang berada pada rentang penilaian belum berkembang dan mulai berkembang, 32\% atau 6 orang anak berada pada rentang penilaian berkembang sesuai harapan dan $68 \%$ atau 13 orang anak berada pada rentang penilaian berkembang sangat baik. Sementara pada aspek anak dapat menghargai keunggulan orang lain tidak ditemukan lagi anak yang berada pada rentang penilaian belum berkembang, 5\% atau 1 orang anak berada pada rentang penilaian mulai berkembang, $42 \%$ atau 8 anak berada rentang penilaian berkembang sesuai harapan dan 53\% atau 10 orang anak berada pada rentang penilaian berkembang sangat baik. Untuk aspek anak memiliki sikap gigih/tidak mudah menyerah tidak ada lagi anak yang berada pada rentang penilaian belum berkembang, $16 \%$ atau 3 orang anak berada pada rentang penilaian mulai berkembang, $37 \%$ atau 7 anak berada rentang penilaian berkembang sesuai harapan dan $47 \%$ atau 9 orang anak berada pada rentang penilaian berkembang sangat baik. Dan pada aspek anak dapat berbagi dengan orang tidak ada lagi anak yang berada pada rentang penilaian belum berkembang, $5 \%$ atau 1 orang anak berada pada rentang penilaian mulai berkembang, $32 \%$ atau 6 anak berada rentang penilaian berkembang sesuai harapan dan 63\% atau 12 orang anak berada pada rentang penilaian berkembang sangat baik.

Berdasarkan data yang diperoleh peneliti dari pelaksanaan tindakan pada siklus satu yang belum mencapai kriteria ketuntasan yaitu tinggi dan sangat tinggi, maka peneliti memutuskan untuk meneruskan pemberian tindakan ke siklus kedua. Pelaksanaan tindakan siklus kedua dilaksanakan selama 3 kali pertemuan yaitu pada tanggal 16-18 september 2019. Data yang diperoleh dari pelaksanaan siklus kedua dapat dilihat pada tabel di bawah ini: 
Tabel 4. Kemampuan Sosial Emosional Anak Siklus Dua

\begin{tabular}{|c|c|c|c|c|c|c|c|c|c|c|c|c|}
\hline \multirow{3}{*}{ Aspek Sosem yang Dinilai } & \multicolumn{4}{|c|}{ Pertemuan 1} & \multicolumn{4}{|c|}{ Pertemuan 2} & \multicolumn{4}{|c|}{ Pertemuan 3} \\
\hline & $\mathrm{B}$ & $\mathrm{M}$ & $\mathrm{BS}$ & $\mathrm{BS}$ & $\mathrm{B}$ & $\mathrm{M}$ & $\mathrm{BS}$ & $\mathrm{BS}$ & $\mathrm{B}$ & $\mathrm{M}$ & $\mathrm{BS}$ & $\mathrm{BS}$ \\
\hline & $\mathrm{B}$ & B & $\mathrm{H}$ & B & $\mathrm{B}$ & $\mathrm{B}$ & $\mathrm{H}$ & B & $\mathrm{B}$ & $\mathrm{B}$ & $\mathrm{H}$ & B \\
\hline $\begin{array}{lll}\begin{array}{l}\text { Anak dapat mengendalikan } \\
\text { perasaan }\end{array} & \\
\end{array}$ & - & $\begin{array}{l}5 \\
\%\end{array}$ & $\begin{array}{l}32 \\
\%\end{array}$ & $\begin{array}{l}62 \\
\%\end{array}$ & - & - & $\begin{array}{l}26 \\
\%\end{array}$ & $\begin{array}{l}74 \\
\%\end{array}$ & - & - & $\begin{array}{l}21 \\
\%\end{array}$ & $\begin{array}{l}79 \\
\%\end{array}$ \\
\hline $\begin{array}{l}\text { Anak dapat menunjukkan } \\
\text { antusiasme dalam melakukan suatu } \\
\text { permainan }\end{array}$ & - & - & $\begin{array}{l}26 \\
\%\end{array}$ & $\begin{array}{l}74 \\
\%\end{array}$ & - & - & $\begin{array}{l}16 \\
\%\end{array}$ & $\begin{array}{l}84 \\
\%\end{array}$ & - & - & $5 \%$ & $\begin{array}{l}95 \\
\%\end{array}$ \\
\hline $\begin{array}{l}\text { Anak dapat menghargai keunggulan } \\
\text { orang lain }\end{array}$ & - & - & $\begin{array}{l}37 \\
\%\end{array}$ & $\begin{array}{l}63 \\
\%\end{array}$ & - & - & $\begin{array}{l}32 \\
\%\end{array}$ & $\begin{array}{l}68 \\
\%\end{array}$ & - & - & $\begin{array}{l}21 \\
\%\end{array}$ & $\begin{array}{l}79 \\
\%\end{array}$ \\
\hline $\begin{array}{l}\text { Memiliki sikap gigih/tidak mudah } \\
\text { menyerah }\end{array}$ & - & $\begin{array}{l}5 \\
\%\end{array}$ & $\begin{array}{l}31 \\
\%\end{array}$ & $\begin{array}{l}64 \\
\%\end{array}$ & - & - & $\begin{array}{l}26 \\
\%\end{array}$ & $\begin{array}{l}74 \\
\%\end{array}$ & - & - & $\begin{array}{l}21 \\
\%\end{array}$ & $\begin{array}{l}79 \\
\%\end{array}$ \\
\hline $\begin{array}{l}\text { Anak dapat berbagi dengan orang } \\
\text { lain }\end{array}$ & - & - & $\begin{array}{l}32 \\
\%\end{array}$ & $\begin{array}{l}68 \\
\%\end{array}$ & - & - & $\begin{array}{l}21 \\
\%\end{array}$ & $\begin{array}{l}79 \\
\%\end{array}$ & - & - & $\begin{array}{l}16 \\
\%\end{array}$ & $\begin{array}{l}84 \\
\%\end{array}$ \\
\hline
\end{tabular}

Berdasarkan data hasil tindakan siklus kedua pertemuan pertama diperoleh perkembangan sosial emosional anak sesuai dengan tabel 3 yaitu pada aspek anak dapat mengendalikan perasaan tidak ada lagi anak yang berada pada rentang penilaian belum berkembang, 5\% atau 1 orang anak berada pada rentang penilaian mulai berkembang, 32\% atau 6 orang anak berada pada rentang penilaian berkembang sesuai harapan dan 63\% atau 12 orang anak berada pada rentang penilaian berkembang sangat baik. Selanjutnya pada aspek anak dapat menunjukkan antusiasme dalam melakukan suatu permainan tidak ada lagi anak yang berada pada rentang penilaian belum berkembang dan mulai berkembang, $26 \%$ atau 5 orang anak berada pada rentang penilaian berkembang sesuai harapan dan $74 \%$ atau 14 orang anak berada pada rentang penilaian berkembang sangat baik. Sementara pada aspek anak dapat menghargai keunggulan orang lain tidak ditemukan lagi anak yang berada pada rentang penilaian belum berkembang dan mulai berkembang, 37\% atau 7 anak berada rentang penilaian berkembang sesuai harapan dan $63 \%$ atau 12 orang anak berada pada rentang penilaian berkembang sangat baik. Untuk aspek anak memiliki sikap gigih/tidak mudah menyerah tidak ada lagi anak yang berada pada rentang penilaian belum berkembang, 5\% atau 1 orang anak berada pada rentang penilaian mulai berkembang, 32\% atau 6 anak berada rentang penilaian berkembang sesuai harapan dan 63\% atau 12 orang anak berada pada rentang penilaian berkembang sangat baik. Dan pada aspek anak dapat berbagi dengan orang 
tidak ada lagi anak yang berada pada rentang penilaian belum berkembang dan mulai berkembang, 32\% atau 6 anak berada rentang penilaian berkembang sesuai harapan dan 68\% atau 13 orang anak berada pada rentang penilaian berkembang sangat baik.

Selanjutnya pertemuan kedua pada pelaksanaan tindakan siklus kedua diperoleh perkembangan sosial emosional anak sesuai dengan tabel 3 yaitu pada aspek anak dapat mengendalikan perasaan tidak ada lagi anak yang berada pada rentang penilaian belum berkembang dan mulai berkembang, $26 \%$ atau 5 orang anak berada pada rentang penilaian berkembang sesuai harapan dan $74 \%$ atau 14 orang anak berada pada rentang penilaian berkembang sangat baik. Selanjutnya pada aspek anak dapat menunjukkan antusiasme dalam melakukan suatu permainan tidak ada lagi anak yang berada pada rentang penilaian belum berkembang dan mulai berkembang, $16 \%$ atau 3 orang anak berada pada rentang penilaian berkembang sesuai harapan dan $84 \%$ atau 16 orang anak berada pada rentang penilaian berkembang sangat baik. Sementara pada aspek anak dapat menghargai keunggulan orang lain tidak ditemukan lagi anak yang berada pada rentang penilaian belum berkembang dan mulai berkembang, 32\% atau 6 anak berada rentang penilaian berkembang sesuai harapan dan $68 \%$ atau 13 orang anak berada pada rentang penilaian berkembang sangat baik. Untuk aspek anak memiliki sikap gigih/tidak mudah menyerah tidak ada lagi anak yang berada pada rentang penilaian belum berkembang dan mulai berkembang, 26\% atau 5 anak berada rentang penilaian berkembang sesuai harapan dan $74 \%$ atau 14 orang anak berada pada rentang penilaian berkembang sangat baik. Dan pada aspek anak dapat berbagi dengan orang tidak ada lagi anak yang berada pada rentang penilaian belum berkembang dan mulai berkembang, $21 \%$ atau 4 anak berada rentang penilaian berkembang sesuai harapan dan $79 \%$ atau 15 orang anak berada pada rentang penilaian berkembang sangat baik.

Pada pertemuan ketiga dari pelaksanaan tindakan siklus kedua diperoleh perkembangan sosial emosional anak sesuai dengan tabel 3 yaitu pada aspek anak dapat mengendalikan perasaan tidak ada lagi anak yang berada pada rentang penilaian belum berkembang dan mulai berkembang, $21 \%$ atau 4 orang anak berada pada rentang penilaian berkembang sesuai harapan dan $79 \%$ atau 15 orang anak berada pada rentang penilaian berkembang sangat baik. Selanjutnya pada aspek anak dapat menunjukkan antusiasme dalam 
melakukan suatu permainan tidak ada lagi anak yang berada pada rentang penilaian belum berkembang dan mulai berkembang, 5\% atau 1 orang anak berada pada rentang penilaian berkembang sesuai harapan dan $95 \%$ atau 18 orang anak berada pada rentang penilaian berkembang sangat baik. Sementara pada aspek anak dapat menghargai keunggulan orang lain tidak ditemukan lagi anak yang berada pada rentang penilaian belum berkembang dan mulai berkembang, $21 \%$ atau 4 anak berada rentang penilaian berkembang sesuai harapan dan $79 \%$ atau 15 orang anak berada pada rentang penilaian berkembang sangat baik. Untuk aspek anak memiliki sikap gigih/tidak mudah menyerah tidak ada lagi anak yang berada pada rentang penilaian belum berkembang dan mulai berkembang, $21 \%$ atau 4 anak berada rentang penilaian berkembang sesuai harapan dan $79 \%$ atau 15 orang anak berada pada rentang penilaian berkembang sangat baik. Dan pada aspek anak dapat berbagi dengan orang tidak ada lagi anak yang berada pada rentang penilaian belum berkembang dan mulai berkembang, $16 \%$ atau 3 anak berada rentang penilaian berkembang sesuai harapan dan $84 \%$ atau 16 orang anak berada pada rentang penilaian berkembang sangat baik.

Perkembangan sosial emosional anak kelompok A usia 4-5 tahun di TK Al-Aqsho Kabupaten Konawe Selatan dapat diidentifikasi dengan baik dan teratur dengan menampilkan grafik kemampuan sosial emosional anak disebelum dan sesudah diberikan tindakan, sebagai berikut:

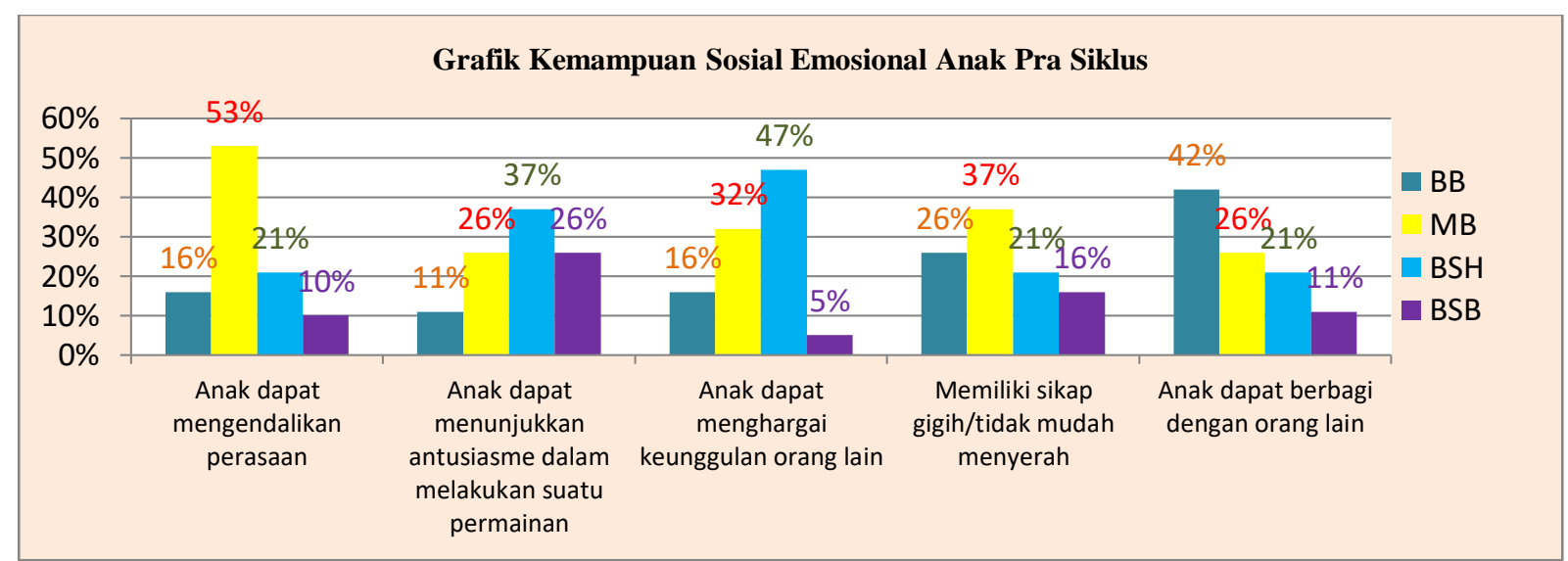

Berdasarkan data yang ada dalam grafik kemampuan sosial emosional anak pra siklus dapat diketahui kemampuan sosial emosional anak sebelum diberikan tindakan yaitu pada aspek anak dapat mengendalikan perasaan sebanyak 53\% anak berada pada rentang penilaian 
mulai berkembang, $21 \%$ anak berada pada rentang penilaian berkembang sesuai harapan, $16 \%$ anak berada pada rentang penilaian belum berkembang dan $10 \%$ anak berada pada rentang penilaian berkembang sangat baik. Aspek selanjutnya anak dapat menunjukkan antusiasme dalam melakukan suatu permainan sebanyak $37 \%$ anak berada pada rentang penilaian berkembang sesuai harapan, $26 \%$ anak berada pada rentang penilaian mulai berkembang dan berkembang sangat baik dan $11 \%$ anak berada pada rentang penilaian belum berkembang. Selanjutnya aspek anak dapat menghargai keunggulan orang lain sebanyak $47 \%$ anak berada pada rentang penilaian berkembang sesuai harapan, $32 \%$ anak berada pada rentang penilaian mulai berkembang, $16 \%$ anak berada pada rentang penilaian belum berkembang dan $5 \%$ anak berada pada rentang penilaian berkembang sangat baik. Pada aspek memiliki sikap gigih/tidak mudah menyerah sebanyak $37 \%$ anak berada pada rentang penilaian mulai berkembang, $26 \%$ anak berada pada rentang penilaian belum berkembang, $21 \%$ anak berada pada rentang penilaian berkembang sesuai harapan dan $16 \%$ anak berada pada rentang penilaian berkembang sangat baik. Aspek terakhir yang dinilai adalah anak dapat berbagi dengan orang lain sebanyak $42 \%$ anak berada pada rentang penilaian belum berkembang, $26 \%$ anak berada pada rentang penilaian mulai berkembang, $21 \%$ anak berada pada rentang penilaian berkembang sesuai harapan dan $11 \%$ anak berada pada rentang penilaian berkembang sangat baik.

Hasil penilaian kemampuan sosial emosional anak berdasarkan grafik pra siklus menunjukkan bahwa lima aspek indikator perkembangan sosial emosional dominan berada pada penilaian mulai berkembang dengan kategori ketuntasan perkembangan sedang, hal ini berarti bahwa capaian perkembangan anak masih sangat rendah. Selanjutnya diberikan tindakan pada siklus satu sebanyak tiga kali pertemuan berupa penggunaan permainan dadu literasi untuk perkembangan sosial emosional anak kemudian dilakukan penilaian untuk melihat capaian perkembangan anak. Adapun capaian perkembangan sosial emosional anak untuk siklus satu yaitu sebagai berikut: 


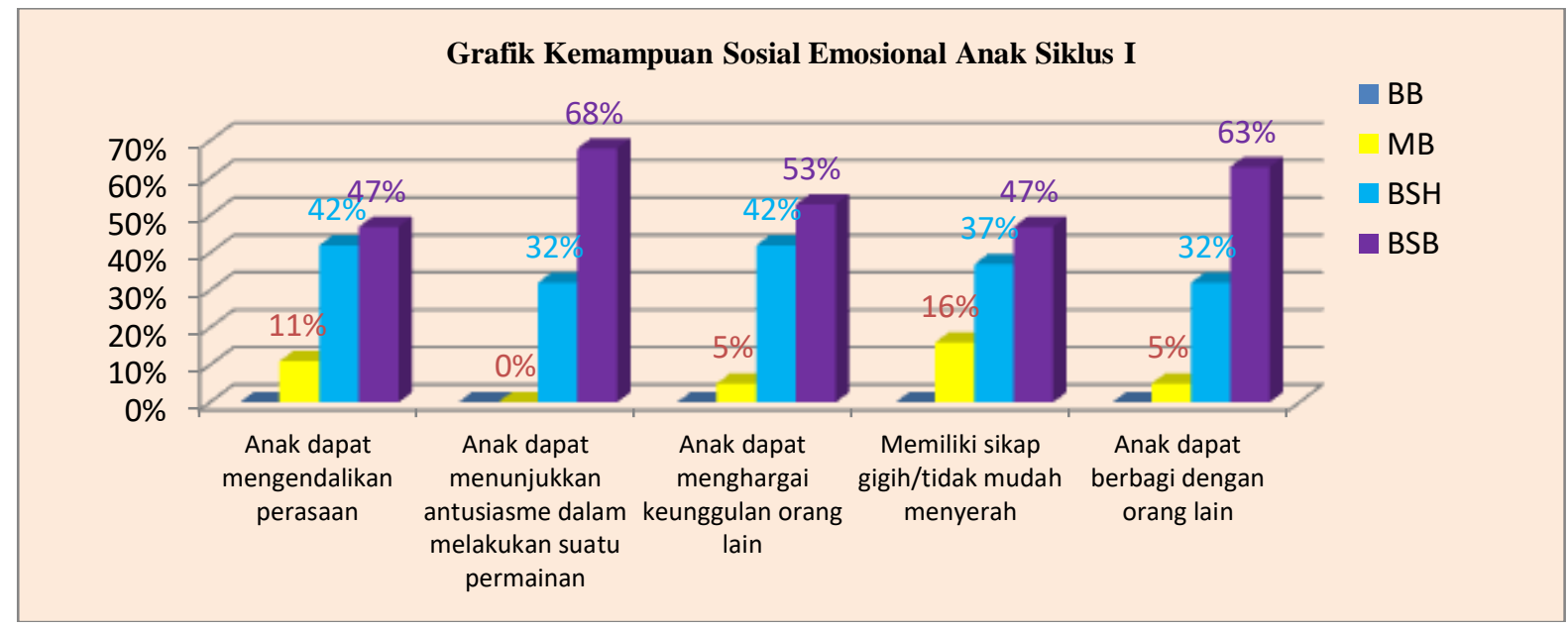

Capaian perkembangan sosial emosional anak pada lima aspek indikator perkembangan yaitu pada aspek anak dapat mengendalikan perasaan sebanyak $47 \%$ anak berada pada rentang penilaian berkembang sangat baik, $42 \%$ anak berada pada rentang penilaian berkembang sesuai harapan, $11 \%$ anak berada pada rentang penilaian mulai berkembang dan tidak ada anak yang berada pada rentang penilaian belum berkembang. Aspek selanjutnya anak dapat menunjukkan antusiasme dalam melakukan suatu permainan sebanyak $68 \%$ anak berada pada rentang penilaian berkembang sangat baik, $32 \%$ anak berada pada rentang penilaian mulai berkembang sesuai harapan dan tidak ada anak yang berada pada rentang penilaian belum berkembang. Selanjutnya aspek anak dapat menghargai keunggulan orang lain sebanyak 53\% anak berada pada rentang penilaian berkembang sangat baik, $42 \%$ anak berada pada rentang penilaian berkembang sesuai harapan, $5 \%$ anak berada pada rentang penilaian mulai berkembang dan tidak ada anak yang berada pada rentang penilaian mulai berkembang. Pada aspek memiliki sikap gigih/tidak mudah menyerah sebanyak $47 \%$ anak berada pada rentang penilaian berkembang sangat baik, $37 \%$ anak berada pada rentang penilaian berkembang sesuai harapan, $16 \%$ anak berada pada rentang penilaian mulai berkembang dan tidak ada anak yang berada pada rentang penilaian belum berkembang. Aspek terakhir yang dinilai adalah anak dapat berbagi dengan orang lain sebanyak $63 \%$ anak berada pada rentang penilaian berkembang sangat baik, 32\% anak berada pada rentang penilaian berkembang sesuai harapan, 5\% anak berada pada rentang penilaian mulai berkembang dan tidak ada anak yang berada pada rentang penilaian belum berkembang. 
Hasil penilaian kemampuan sosial emosional anak berdasarkan grafik siklus satu menunjukkan bahwa lima aspek indikator perkembangan sosial emosional dominan berada pada penilaian berkembang sangat baik dengan kategori ketuntasan perkembangan sedang, hal ini berarti bahwa capaian perkembangan anak sangat baik namun ketuntasan belajar masih berada pada kategori sedang. kemudian dilanjutkan pada siklus kedua yaitu penggunaan permainan dadu literasi untuk perkembangan sosial emosional anak. Adapun capaian perkembangan sosial emosional anak untuk siklus dua yaitu sebagai berikut:

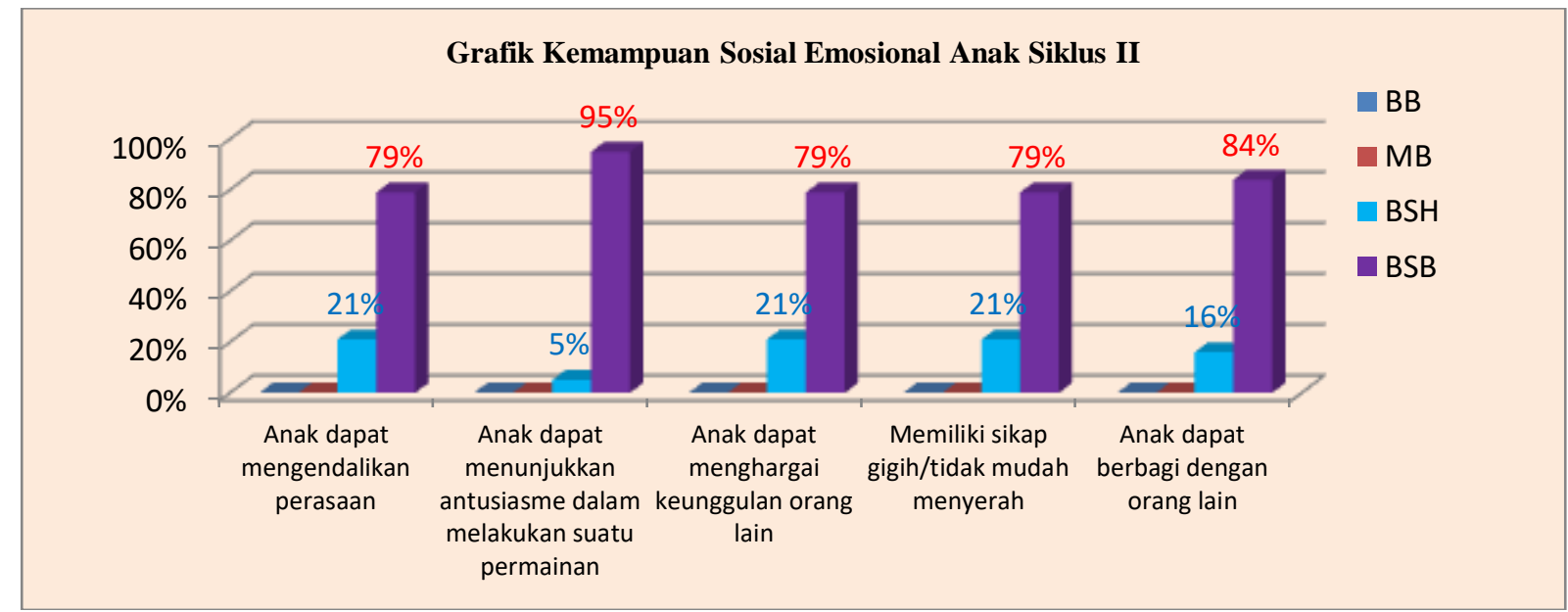

Capaian perkembangan sosial emosional anak pada lima aspek indikator perkembangan yaitu pada aspek anak dapat mengendalikan perasaan sebanyak $79 \%$ anak berada pada rentang penilaian berkembang sangat baik, $21 \%$ anak berada pada rentang penilaian berkembang sesuai harapan, dan tidak ada anak berada pada rentang penilaian mulai berkembang dan belum berkembang. Aspek selanjutnya anak dapat menunjukkan antusiasme dalam melakukan suatu permainan sebanyak 95\% anak berada pada rentang penilaian berkembang sangat baik, $5 \%$ anak berada pada rentang penilaian mulai berkembang sesuai harapan dan tidak ada anak berada pada rentang penilaian mulai berkembang dan belum berkembang. Selanjutnya aspek anak dapat menghargai keunggulan orang lain sebanyak 79\% anak berada pada rentang penilaian berkembang sangat baik, $21 \%$ anak berada pada rentang penilaian berkembang sesuai harapan, dan tidak ada anak berada pada rentang penilaian mulai berkembang dan belum berkembang. Pada aspek memiliki sikap gigih/tidak mudah menyerah 
sebanyak $79 \%$ anak berada pada rentang penilaian berkembang sangat baik, $21 \%$ anak berada pada rentang penilaian berkembang sesuai harapan, dan tidak ada anak berada pada rentang penilaian mulai berkembang dan belum berkembang. Aspek terakhir yang dinilai adalah anak dapat berbagi dengan orang lain sebanyak $84 \%$ anak berada pada rentang penilaian berkembang sangat baik, $16 \%$ anak berada pada rentang penilaian berkembang sesuai harapan dan tidak ada anak berada pada rentang penilaian mulai berkembang dan belum berkembang.

Hasil penilaian kemampuan sosial emosional anak berdasarkan grafik siklus dua menunjukkan bahwa lima aspek indikator perkembangan sosial emosional memiliki capaian perkembangan pada penilaian berkembang sangat baik dengan kategori ketuntasan perkembangan sangat tinggi dan tinggi sehingga pelaksanaan tindakan dihentikan karena telah mencapai kriteria maksimal baik dari sisi capaian perkembangan sosial emosional anak dengan melihat lima indikator perkembangan yang ada maupun dari sisi ketuntasan perkembangan yang berada pada kategori tinggi dan sangat tinggi.

Berdasarkan hasil temuan penelitian yang telah kemukakan bahwa penggunaan permainan dadu literasi untuk memberikan stimulasi pada perkembangan sosial emosional anak usia 4-5 tahun pada lima indikator perkembangan yaitu anak dapat mengendalikan perasaan, anak dapat memahami peraturan dan disiplin, anak dapat menunjukkan antusiasme dalam melakukan suatu permainan, anak dapat menghargai keunggulan orang lain, Memiliki sikap gigih/tidak mudah menyerah dan Anak dapat berbagi dengan orang lain memiliki capaian perkembangan pada penilaian yaitu berkembang sangat baik (BSB) dengan kategori ketuntasan perkembangan sangat tinggi (95\% dan 84\%) dan tinggi (79\%). Temuan penelitian ini memperkuat temuan sebelumnya bahwa permainan dadu dapat meningkatkan perkembangan kognitif anak dalam berhitung (Joni, 2016, p. 10). Febrianti juga mengemukakan bahwa permainan dadu berpengaruh terhadap kemampuan menghitung 1-6 pada anak cerebral palsy (Febriyanti, 2014). Begitu juga dengan hasil penelitian dari Anggraeni dan Wahyono yang menyatakan bahwa permainan dadu dapat memudahkan anak tunagrahita dalam belajar dan permainan dadu membantu anak memiliki kemampuan berhitung (Anggraini, T. D., dan Wahyuno, 2015, p. 25). Hasil-hasil penelitian yang telah dilakukan oleh peneliti-peneliti terdahulu tentang permainan dadu mendukung temuan 
peneliti bahwa permainan dadu literasi dapat mengembangkan kemampuan sosial emosional anak. Ananda dan Fadhilaturrahmi mengemukakan bahwa permainan kolaboratif dapat meningkatkan kemampuan sosial emosional anak KB (Ananda, Rizki dan Fadhilaturrahmi, 2018, p. 20). Begitu juga dengan hasil penelitian yang dilakukan oleh Hewi dan Surpida yang menyatakan bahwa permainan dadu dapat mengembangkan perilaku prososial anak (Hewi, 2019, p. 126). Hal yang sama juga diungkapkan oleh Duha dan Widiastuti bahwa kemampuan sosial emosional anak dapat ditingkatkan melalui permainan role playing (Duha, Refisi dan Widiastuti, 2018, p. 86). Seluruh temuan penelitian yang telah dikemukakan menunjukkan bahwa permainan dapat meningkatkan perkembangan anak karena aktivitas utama dari anak usia dini adalah bermain dan melalui bermain anak belajar.

\section{SIMPULAN}

Berdasarkan hasil dan pembahasan yang telah dikemukakan, dapat diambil simpulan bahwa permainan dadu literasi dapat mengembangkan kemampuan sosial emosional anak usia 4-5 tahun di TK Al-Aqsho Kabupaten Konawe Selatan pada lima indikator perkembangan yaitu anak dapat mengendalikan perasaan, anak dapat memahami peraturan dan disiplin, anak dapat menunjukkan antusiasme dalam melakukan suatu permainan, anak dapat menghargai keunggulan orang lain, Memiliki sikap gigih/tidak mudah menyerah dan Anak dapat berbagi dengan orang lain.

\section{DAFTAR PUSTAKA}

Ananda, Rizki dan Fadhilaturrahmi, F. (2018). Peningkatan Kemampuan Sosial Emosional melalui Permainan Kolaboratif pada Anak KB. Obsesi: Jurnal Pendidikan Anak Usia Dini, 2(1), 20-26.

Andriyani, P. W. S., Raga, G., \& Suartama, I. K. (2013). Penerapan Metode Demonstrasi Berbantuan Media Dadu Untuk Meningkatkan Kemampuan Mengenal Konsep Bilangan Pada Anak di TK Widya Suta Kerti Sulanyah. Jurnal Pendidikan Anak Usia Dini Undiksha, 1(1), 1-11.

Anggraini, Tristanti Dewi dan Wahyuno, E. (2015). Pengaruh Penggunaan Media Permainan Dadu Terhadap Kemampuan Berhitung Pada Anak Tunagrahita Kelas 1. Jurnal Penelitian Dan Pengembangan Pendidikan Luar Biasa, 2(1), 22-26.

Arikunto, S. (2009). Penelitian Tindakan Kelas. Jakarta: Bumi Aksara. 
Arikunto, S. (2013). Prosedur Penelitian suatu Pendekatan Praktik. Jakarta: Rineka Cipta.

Desmita. (2013). Psikologi Perkembangan. Bandung: Remaja Rosdakarya.

Duha, Refisi dan Widiastuti, A. A. (2018). Meningkatkan Kemampuan Sosial Emosional Anak Melalui Metode Role Playing di Kelompok Bermain. Satya Widya, 34(1), 77-87.

Febriyanti, I. M. (2014). Pengaruh Permainan Dadu Terhadap Kemampuan Menghitung 1-6 Dalam Pelajaran Matematika Pada Anak Cerebal Palsy (CP) Di SDLB D/D1 YPAC Malang. Universitas Negeri Malang.

Hewi, L. dan S. (2019). Permainan Dadu pada Pengembangan Perilaku Prososial Anak di RA An-Nur Kota Kendari. JECED: Journal of Early Childhood Education and Development, 1(2), 115-128.

Hurlock, E. B. (2013). Perkembangan Anak (Keenam). Jakarta: Erlangga.

Iskandar. (2009). Penelitian Tindakan Kelas. Jakarta: Gaung Persada Press.

Jawati, R. (2013). Peningkatan Kemampuan Kognitif Anak Melalui Permainan Ludo Geometri di PAUD Habibul Ummi II. Spektrum: Jurnal Pendidikan Luar Sekolah (PLS), $1(1), 250-263$.

Joni. (2016). Peningkatan Kemampuan Kognitif Anak dalam Kegiatan Berhitung dengan Permainan Dadu TK Mutiara Pekanbaru. Obsesi: Jurnal Pendidikan Anak Usia Dini, 2(1), 1-10.

Khasanah, I., Prasetyo, A. dan R. E. (2011). Permainan Tradisional sebagai Media Stimulasi Aspek Perkembangan Anak Usia Dini. Jurnal Penelitian PAUDIA, 1(1), 91-105.

Kuntjojo, S. dan. (2016). Pengembangan Model Permainan Pra-calistung Anak Usia Dini. Jurnal Pendidikan Usia Dini, 10(2), 255-276.

Munawaroh, H. (2017). Pengembangan Model Pembelajaran dengan Permainan Tradisional Engklek Sebagai Sarana Stimulasi Perkembangan Anak Usia Dini. Obsesi: Jurnal Pendidikan Anak Usia Dini, 1(2), 86-96.

Nurbayani, Y. (2011). Pengaruh Penerapan Bermain Dengan Dadu Geometri Terhadap Keterampilan Sosial Dan Kemampuan Berhitung Permulaan Anak Usia Dini (Doctoral Dissertation, Universitas Pendidikan Indonesia).

Nurmalitasari, F. (2015). Perkembangan Sosial Emosi pada Anak Usia Pra Sekolah. Buletin Psikologi, 23(2), 103-111.

Papalia, D. E. dan R. D. F. (2015). Menyelami Perkembangan Manusia. Jakarta: Salemba Humanika. 
Purwanto, N. (2009). Prinsip-Prinsip dan Teknik Evaluasi Pengajaran. Bandung: Remaja Rosdakarya.

Putri, A. R. N. (2013). Efektivitas Permainan Tradisional Jawa dalam Meningkatkan Penyesuaian Sosial pada Anak Usia 4-5 Tahun di Kecamatan Suruh. BELIA: Early Childhood Education Papers, 2(1).

Rohmah, N., R. dan A. R. (2016). Keefektifan Pembelajaran Kooperatif melalui Media Dadu dalam Pengembangan Kemampuan Matematika Bagi Anak Usia Dini. Journal of Primary Education, 5(1), 42-48.

Santrock, J. W. (2012). Psikologi Pendidikan. Jakarta: Salemba Humanika.

Satriana, M. (2013). Permainan Tradisional Berbasis Budaya Sunda Sebagai Sarana Stimulasi Perkembangan Anak Usia Dini. Jurnal Pendidikan Usia Dini, 7(1), 65-84. 